\title{
Small field islands systems include a large proportion of the regional orthopteran species pool in arable landscapes
}

\author{
Laura G. A. Riggi ${ }^{1}$ (D) Åsa Berggren ${ }^{1}$ (i)
}

Received: 23 November 2019 / Accepted: 29 April 2020 / Published online: 12 May 2020

(c) The Author(s) 2020

\begin{abstract}
The tendency of species richness to increase with patch area is one of the most robust empirical generalisations in ecology and its logic drives conservation actions. Indeed, preference is often given to conserving large, highly connected areas over small isolated patches. However, small habitats have been shown to be important biodiversity refuges in managed landscapes. Field islands are small remnants of natural habitat patches surrounded by cropland. While their island-like position in a species-poor crop field makes them potentially strategic habitats for biodiversity conservation, they have not received much attention in ecological studies. We investigated how local (i.e. field island area and habitat diversity) and landscape factors (i.e. proportion of arable land) affected orthopteran species richness, community mean dispersal and habitat specificity in 71 field islands in central Sweden. We found that despite low numbers of species per field island, due to their intrinsic small size, taken together, a system of small field island increased species richness and included a large proportion of the regional species pool in the arable landscape in central Sweden. Furthermore, we found that patch area and habitat diversity determined orthopteran community composition in field islands. More diverse and, to a lesser extent, larger field islands benefit sedentary and habitat specialist species. This study shows that more care should be taken to incorporate and potentially also prioritize small and permanent habitat patches in the management of agricultural landscapes. The protection of field islands with diverse habitats may be important for the maintenance of sedentary and specialist species.
\end{abstract}

Keywords Field island $\cdot$ Small natural features $\cdot$ Orthopteran $\cdot$ Conservation $\cdot$ Agricultural intensification

\section{Introduction}

The expansion of agriculture has been a major driver of grassland loss worldwide and is one of the main factors for the observed decline in arthropod diversity (Stoate et al. 2009; Sánchez-Bayo and Wyckhuys 2019). As a consequence, the development of landscape's green infrastructures to mitigate biodiversity declines has become a target for national and international authorities (EU Environment; The Nature Conservancy; NCE 2016; Sverige and Naturvårdsverket 2016). Despite political interest to conserve

Electronic supplementary material The online version of this article (https://doi.org/10.1007/s10841-020-00245-z) contains supplementary material, which is available to authorized users.

Laura G. A. Riggi

Laura.Riggi@slu.se

1 Department of Ecology, Swedish University of Agricultural Sciences, Uppsala, Sweden natural habitats in agricultural landscapes, many small habitats are not included in these strategies. This is partly because ecological studies have mainly focused on large and species-rich habitats, while small habitats in managed landscapes have been less valued (Tulloch et al. 2016; Fahrig 2019; Wintle et al. 2019). However, small habitats, such as field verges (Öckinger and Smith 2007; Jakobsson et al. 2016), field islands (Cousins 2006; Plue and Cousins 2013; Lindgren et al. 2018; Deák et al. 2018), fences, stonewalls (Pulsford et al. 2017; Poschlod and Braun-Reichert 2017), single trees (Gibbons and Boak 2002; Manning et al. 2006; Le Roux et al. 2015; Lindenmayer and Laurance 2017) and ditches (Aavik et al. 2008) have been shown to be important biodiversity refuges in managed landscapes around the world. Agricultural intensification has destroyed many of these small habitats and there is a concern that this decline will continue if their conservation value is not recognized (Poschlod and Braun-Reichert 2017; Lindenmayer 2019; Wintle et al. 2019). Promoting the conservation value of "all bits of habitat, not only the large, contiguous ones" (Fahrig 
2019) requires a better knowledge of factors, at the local and landscape scale, affecting species richness and densities in these small habitats.

Field islands are small remnants of natural habitat patches surrounded by cropland (Fig. 1). They vary in size usually between a few square meters to about 1 ha. Often, these are where farmers gathered stones from the field and have been part of the European cropland landscapes since the establishment of agriculture in the eighteenth century. Their island-like position in a species-poor crop field makes them potentially strategic habitats for biodiversity, providing habitat for plant or animal populations. However, while field islands have been suggested to act as keystone habitats in agricultural landscapes for plant richness (Plue and Cousins 2013; Lindgren and Cousins 2017; Deák et al. 2018), very few studies have investigated animal communities in these habitats. One notable exception is Lindgren and colleagues (Lindgren et al. 2018), who investigated multiple ecosystem services provided by animals in field islands (i.e. pollination, biological control and seed predation). While animal communities were not directly quantified, field islands were shown to support ecosystem services suggesting that these habitats can increase services in agricultural landscapes.

Like true islands, field islands also provide a useful system where to test basic ecological theories such as area-richness (MacArthur and Wilson 1967; Rosenzweig
1995). The habitat diversity hypothesis predicts that larger patches are more likely to contain greater habitat diversity and, therefore, more species as predicted by niche theory (Rosenzweig 1995). However, unlike marine environments, the landscape surrounding field islands is likely to modify the richness of species (matrix quality hypothesis) (Fahrig 2001; Brotons et al. 2003). A landscape of high quality is expected to increase richness of species especially in small habitat patches (Estades 2001; Öckinger and Smith 2007). Furthermore, according to theory, richness of more specialized species and of species with low mobility are predicted to be more strongly affected when patches are surrounded by low quality landscapes compared to more generalists and more mobile species (Watson et al. 2005; Ewers and Didham 2006). Investigations of the relative and interactive effects of patch area, patch habitat diversity, landscape composition and species traits (dispersal ability and habitat specificity) on species richness in field islands has important implications for conservation of these habitats in managed landscapes and knowledge of these interactions are needed.

To improve our understanding of how these ecological factors affect insect species richness, we investigated field islands in the agricultural landscapes of central Sweden. Orthopterans were chosen as a model system as they are important indicators of habitat disturbance and quality (Fartmann et al. 2012; Weiss et al. 2013). The main aims of this

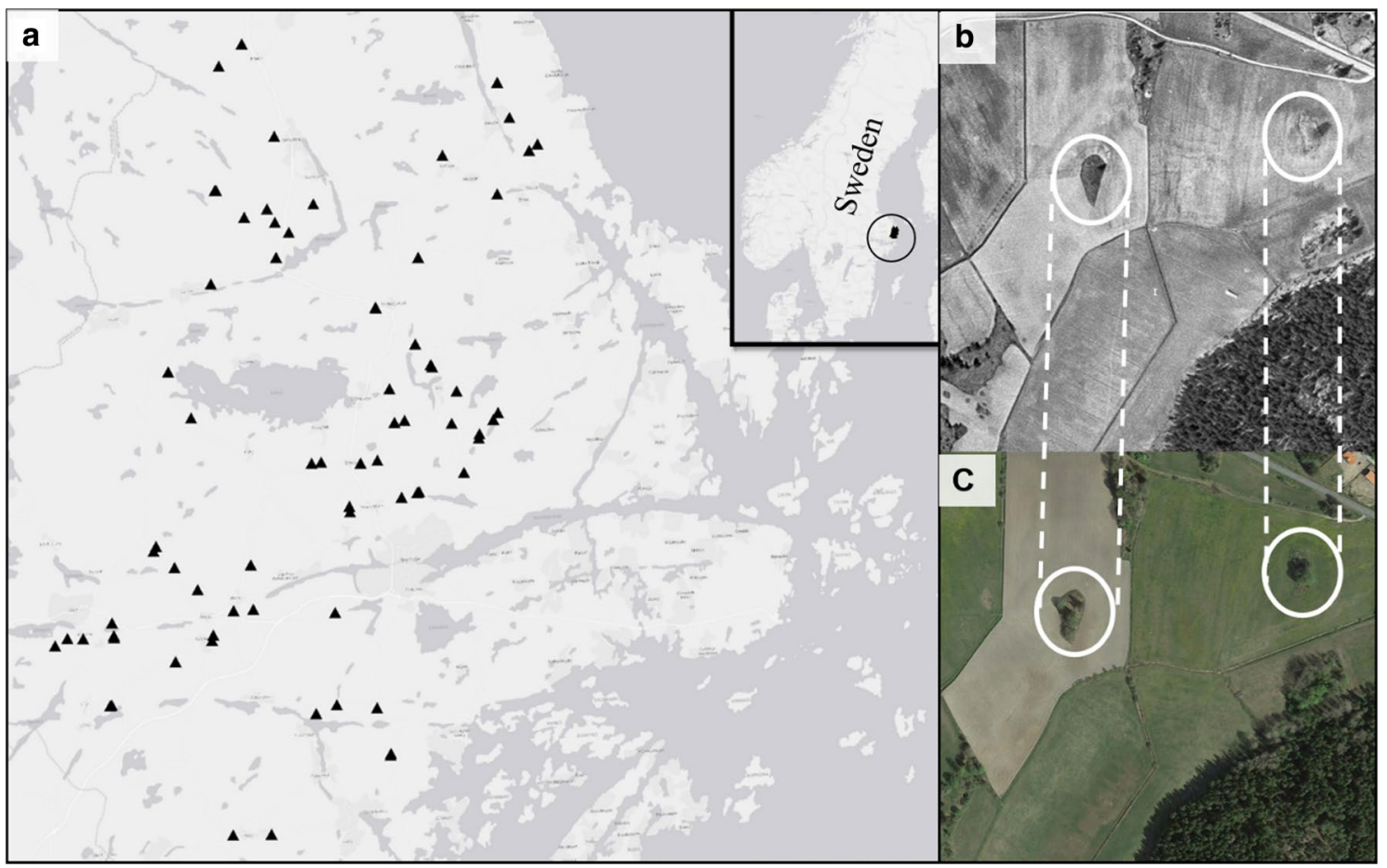

Fig. 1 Map showing a the location of the studied 71 midfield islands located in central Sweden $\left(59^{\circ} 49^{\prime} \mathrm{N}, 18^{\circ} 36^{\prime} \mathrm{E}\right)$. Photos show satellite images of two of the studied midfield islands in their landscape, circled in white, from b 1960 and c 2019, illustrating that these habitats have remained relatively stable over long periods 
study were to investigate how field island area and habitat diversity, mediated by landscape composition (measured as proportion of arable land in a $250 \mathrm{~m}$ radius), affect (i) overall orthopteran species richness and (ii) mean community mobility and habitat specificity indices reflected by the Species Farmland Index. We explored these relationships in 71 field islands in arable landscapes in central Sweden. Overall, we expected field islands to be good habitats for orthopterans and to harbor a large fraction of the regional species pool. Specifically, we hypothesized that both field island area and habitat diversity would have a positive effect on orthopteran species richness, and that these effects would be stronger in low quality, simplified landscapes with high proportion of arable land. Furthermore, we expected sedentary and specialist organisms, that is organisms more dependent on high nature value farmlands (Fumy et al. 2020), to be more negatively affected by landscape simplification than mobile generalist organisms and therefore hypothesized that field islands embedded in low quality landscapes would be dominated by mobile widespread species.

\section{Material and methods}

\section{Study area and field islands}

The study took place in central Sweden $\left(59^{\circ} 49^{\prime} \mathrm{N}, 18^{\circ} 36^{\prime}\right.$ E) in 2008.71 field islands were sampled between 30 August and 25 September (Fig. 1). The study area covered $\sim 1400$ $\mathrm{km}^{2}$ and was characterized by a mix of arable land (16\%) and forests $(65 \%)$. The main agricultural use of the arable land in this area is for ley (37\%), cereal (23\%), pasture (13\%) and fallow land $(11 \%)$. Field islands have a long history in this landscape as in other parts of northern Europe, and are not used directly for production. This disuse usually arises because of practical reasons; e.g. larger stones have been collected over the years from tillage or the island is based on Iron Age burial remains. In these areas grasses, herbs, bushes and trees have established and form a patch of semi-natural habitat that is left un-managed within the arable field. The field islands and the associated plant communities therefore have different features, composition and disturbance than the surrounding habitats (Cousins 2006; Lindgren and Cousins 2017).

\section{Local and landscape parameters}

Field island area was calculated using aerial photographs from 2008. The cover of the field islands was estimated in the field during the orthopteran sampling period in 2008. The cover was classified into four categories: grasses and herbs, bushes, trees, and stones. Field island habitat diversity was calculated using a Shannon diversity index using the relative proportion of the four cover categories. Prior to analysis, we checked that correlation between field island area and habitat diversity was low (Pearson's rho $=0.36$ ). To collect land use data we used the land cover data from the Swedish Board of Agriculture. The Land Parcel Identification System (LPIS; 1:10,000; 2008) provided data on the proportion of the area grown for crops in 2008. Landuse data were extracted for $250 \mathrm{~m}$ radii around each field island centroid using ArcMap 10 (ESRI). Since the majority of the species have shorter average dispersal distance, this scale was found to be suitable to represent the landscape used by orthopterans (Kindvall 1999; Berggren et al. 2001; Marini et al. 2009). The areas not used for agricultural purposes were to a large extent covered by forest (Pearson's rho $=-0.93$, p-value $<0.0001$ at $250 \mathrm{~m}$ ). Patch and landscape data for the field islands are presented in Table 1.

\section{Orthoptera sampling}

We surveyed the grasshopper communities using a standard censusing technique: listening for species-specific male stridulation (Riede 1998; Berggren et al. 2002; Gardiner et al. 2005). Transects were placed around the entire edge of the island as well as across the patch area. An ultrasound detector was not used as track-density was high making habitats censused close to the examiner. The census effort (time spent per unit area) was similar over all islands with a walking speed of 3-4 s/m $\mathrm{m}^{2}$. This made it possible to census the whole patch. Censuses was only done at temperatures $>18{ }^{\circ} \mathrm{C}$, wind $<3 \mathrm{~m} / \mathrm{s}$ and in sunny weather. Surveys were done during the orthopteran reproductive period (in

Table 1 Local and landscape characteristics of the 71 midfield islands and their mean and standard error of the mean (SE)

\begin{tabular}{|c|c|}
\hline Variable & Mean \pm SE \\
\hline \multicolumn{2}{|l|}{ Patch } \\
\hline Patch area $\left(\mathrm{m}^{2}\right)$ & $580.7 \pm 56.2$ \\
\hline Perimeter (m) & $90.3 \pm 4.6$ \\
\hline Isolation $^{\mathrm{a}}(\mathrm{m})$ & $21.5 \pm 2.8$ \\
\hline Habitat diversity ${ }^{\mathrm{b}}$ & $1.27 \pm 0.02$ \\
\hline \multicolumn{2}{|l|}{ Landscape } \\
\hline Arable land (\%) & $57.2 \pm 2.7$ \\
\hline Grassland (\%) & $1 \pm 0.5$ \\
\hline Forest (\%) & $19.8 \pm 2.8$ \\
\hline Field margins ${ }^{\mathrm{c}}(\mathrm{km})$ & $3.7 \pm 0.1$ \\
\hline
\end{tabular}

The landscape variables were collected from a radius of $250 \mathrm{~m}$ around the field island

${ }^{a}$ Distance from the edge of the midfield island to the closest field margin

${ }^{\mathrm{b}}$ Habitat Shannon diversity index

${ }^{\mathrm{c}}$ Calculated as the total length of field perimeters 
central Sweden approximately June-September, depending on weather) to ensure that all species present should have had stridulating mature adults at the time of sampling.

\section{Orthopteran Indices}

We classified Orthopterans by their dispersal ability (high $=\mathrm{H}$ or low $=\mathrm{L}$ ), and their habitat preferences concerning high nature value farmland (Species Farmland Index (SFI)) according to Fumy et al. (2020) and Reinhardt et al. (2005) (Table 2). All long-winged species which are known to have a good flight capability were classified as high mobility species. For a measure of species habitat preference, we used Fumy et al. (2020) SFI, based on German Orthopteran distribution data. This indicates the relationship between the distribution of a species and the availability of high-nature-value farmland in its range. When SFI values were not available, for example for Chorthippus albomarginatus, Metrioptera roeselii and Tettigonia viridissima, we averaged the SFI values from species within the same family. Community mean dispersal (CMD) and community farmland index (CFI) for the orthopteran assemblages at each field island were calculated as the unweighted average of the binary mobility classes ( $\mathrm{H}$ and $\mathrm{L}$ ) and of the continuous SFI values.

\section{Statistical analyses}

We examined the effect of field island area, habitat diversity, landscape composition (measured as proportion of arable land in the landscape at $250 \mathrm{~m}$ ) and their interactions on

Table 2 List of all Orthoptera species recorded in the 71 study areas in central Sweden $\left(59^{\circ} 49^{\prime} \mathrm{N}, 18^{\circ} 36^{\prime} \mathrm{E}\right)$ classified by their dispersal ability (DA; $1=$ high mobility; $0=$ low mobility), habitat specificity (HS; $1=$ generalists, $0=$ specialists) and species Farmland Index (SFI; adapted from Fumy et al. 2020)

\begin{tabular}{llll}
\hline Species & DA & HS & SFI \\
\hline Chorthippus albomarginatus & 1 & 1 & $16.19^{*}$ \\
Chorthippus biguttulus & 1 & 1 & 16.04 \\
Chorthippus brunneus & 1 & 0 & 16.34 \\
Dectius verrucivorus & 0 & 0 & 25.9 \\
Gomphocerippus rufus & 0 & 1 & 20.18 \\
Stethophyma grossum & 1 & 0 & 17.68 \\
Metrioptera brachyptera & 0 & 1 & 20.24 \\
Metrioptera roeselii & 0 & 1 & $15.9 *$ \\
Omocestus viridulus & 0 & 1 & 18.68 \\
Pholidoptera griseoaptera & 0 & 1 & 16.12 \\
Pseudochorthippus parallelus & 0 & 1 & 16.03 \\
Tettigonia viridissima & 1 & 1 & $18.45^{*}$ \\
\hline
\end{tabular}

*SFI not available for these species and value rounded to the average of the SFI for the respective family species richness (measured as species counts), community mean dispersal (CMD) and community mean SFI (CSF) using multimodel inference. Interactions between local patch characteristics and landscape variables were included to test the hypothesis that area and patch diversity effects would be stronger in simplified landscapes with high proportion of arable land.

All statistical analyses were performed using R ( R version 3.5.1). Prior to analyses, data was visually checked for normality and equal variances. Orthopteran CMD and CFI were fitted using a linear model $(\mathrm{lm})$ with a normal distribution. Species count was fitted using a poisson distribution $(\mathrm{glm})$ to account for discrete count data. Collinearity between predictor variables was checked in models without interactions using the variance inflation factor (VIF). All predictor variables had VIF values below 2 indicating low collinearity (Zuur et al. 2009). All response variables were tested for spatial autocorrelations using Moran's I test. No significant spatial correlation was found.

For all the response variables, we fitted three predictor variables in the global model: two two-orders interactions between proportion of arable land in the landscape and patch area; and proportion of arable land in the landscape and patch habitat diversity. Provided that a shift was apparent in species richness-area relationship, we then used a breakpoint (or piecewise regression) model to identify the threshold value of patch area marking the change in species richness. The breakpoint between the two best fitting straight lines was determined using the R-package 'segmented' (Muggeo 2003).

The model selection process was performed using stepwise regression and removing non-significant variable according to the second order Akaike information criterion (AIC) (Zuur et al. 2009). Patch isolation and total edge length in the landscape varied between patches (Supplementary Material F1). We therefore tested how species richness, CMD and CFI were affected by these variables. We found no effect of these variables and they were excluded from the analyses.

\section{Results \\ Orthopteran richness}

The total number of orthopteran species sampled was 12 (average $=3.4 ; \min =0 ; \max =8$ ), with 1301 individuals recorded (Table 2). There was a marginal positive effect of field island area $(\mathrm{p}$-value $=0.08)$ and significant negative effect of proportion of arable land in the landscape on species richness (p-value $=0.04)$ (Table 3, Fig. 2). Patch area and proportion of arable land explained $10 \%$ of the variation in species richness at $250 \mathrm{~m}$. As observed in Fig. 2a, the 
Table 3 Summary of the best models for orthopteran richness, community mean dispersal (CMD) and community mean farmland index $(\mathrm{CFI})$

\begin{tabular}{|c|c|c|c|c|c|c|c|c|c|}
\hline \multirow[t]{2}{*}{ Variables } & \multicolumn{3}{|c|}{ Species richness } & \multicolumn{3}{|c|}{$\begin{array}{l}\text { Community mobility } \\
\text { (CMD) }\end{array}$} & \multicolumn{3}{|c|}{$\begin{array}{l}\text { Community Farmland } \\
\text { Index (CFI) }\end{array}$} \\
\hline & Est & $\mathrm{p}$ & $\mathrm{R}^{2}$ & Est & $\mathrm{p}$ & $\mathrm{R}^{2}$ & Est & $\mathrm{p}$ & $\mathrm{R}^{2}$ \\
\hline \multicolumn{10}{|l|}{ Patch } \\
\hline Patch area $\left(\mathrm{m}^{2}\right)$ & $2.29 \mathrm{E}-04$ & 0.082 & 0.1 & $-9.98 \mathrm{E}-05$ & 0.05 & 0.17 & $6.48 \mathrm{E}-04$ & 0.07 & 0.12 \\
\hline Habitat diversity & - & & & -0.24 & 0.02 & & 1.52 & 0.04 & \\
\hline \multicolumn{10}{|l|}{ Landscape } \\
\hline Arable land (\%) & $-5.60 \mathrm{E}-03$ & 0.04 & & - & & & - & & \\
\hline
\end{tabular}

Est estimate, $p,-$ variable not included in the final best model a

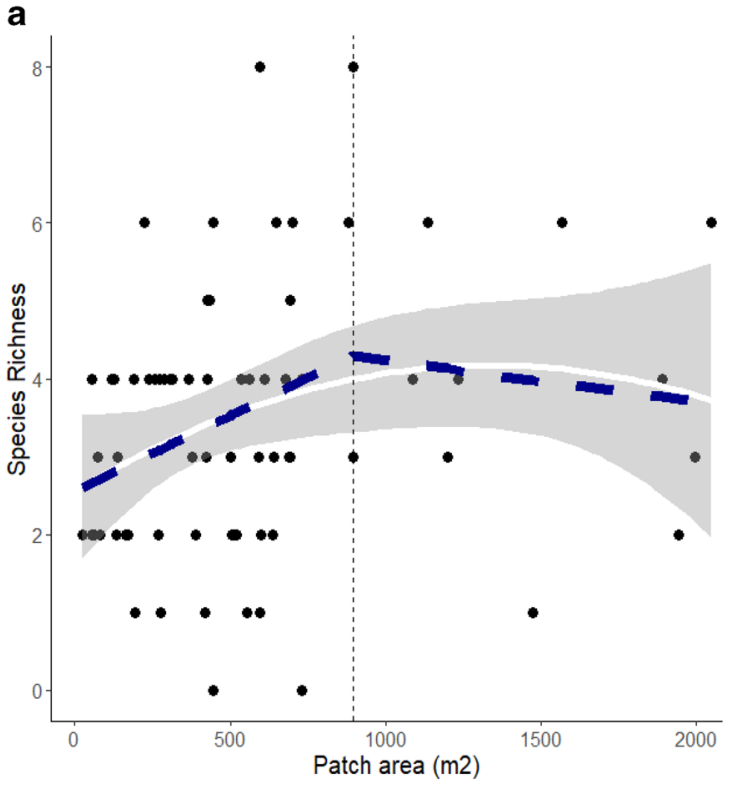

Fig. 2 Orthopteran species richness plotted as a function of a patch area $\left(\mathrm{m}^{2}\right)$ and $\mathbf{b}$ proportion of arable land at $250 \mathrm{~m}$ radius. In a the broken line indicates the critical value beyond which species richness

relationship between species richness and patch area is nonlinear with a threshold (split-line regression: breakpoint for patch area $=894 \mathrm{~m})$. Species richness increases with patch area before this critical point $(\mathrm{e}=0.002$, $\mathrm{p}$-value $=0.05)$, but does not beyond it $(\mathrm{e}=-0.0005$, $\mathrm{p}$-value $>0.05)$.

\section{Community analyses}

Both field island area and habitat diversity had a negative effect on community mean dispersal (CMD), that is, communities dominated by less mobile organisms tended to be on larger and more diverse field islands (Table 3, Fig. 3). Patch area and habitat diversity explained $17 \%$ of the variation in $\mathrm{CMD}$. The community mean farmland index (CFI) was positively correlated with patch habitat diversity, that is, organisms dependent of high nature value farmland were more often found on more diverse field islands (Fig. 4a, Table 3).

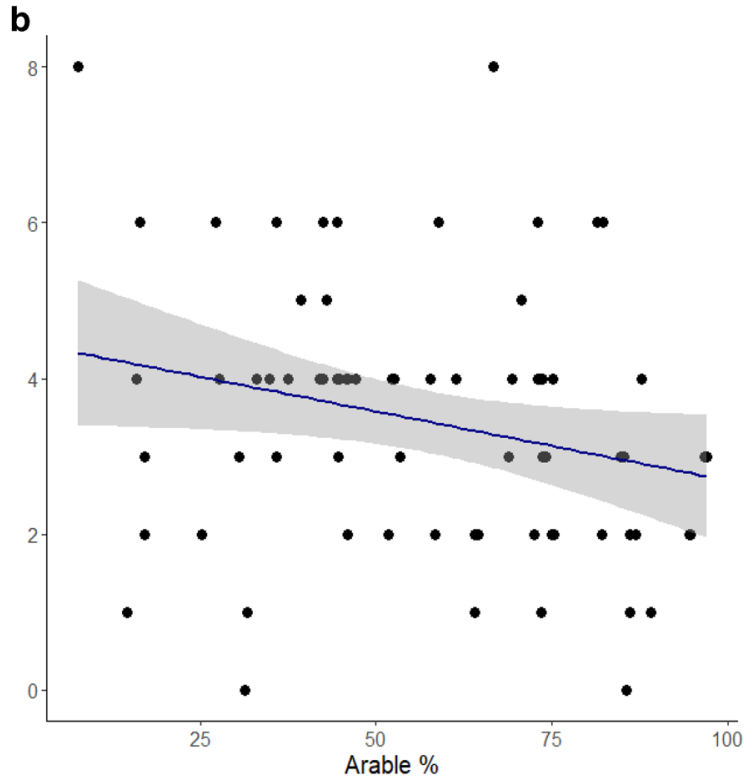

stops increasing. This critical point $(x=894 \mathrm{~m})$ was obtained using split-line regression analyses. There is no significant relationship between species richness and patch area beyond this point

A marginal positive effect of field island area on CFI was also found (p-value $=0.07)($ Fig. 4b, Table 3$)$.

\section{Discussion}

The species that we found on the field islands were representative of the stridulating orthopteran species pool found in grassland habitats in central Sweden (Strid 2010). Only Myrmeleotettix maculatus (Mottled grasshopper), a nutrientpoor habitat specialist species was not found in the field islands (Kindvall Pers. Comm.). Altogether, field islands harbored a large proportion of the Swedish orthopteran species richness, and did not need to be very large $\left(\sim 900 \mathrm{~m}^{2}\right)$ to reach a threshold in species richness, suggesting that small field island are potentially as important as large field islands for orthopterans in managed landscapes. 

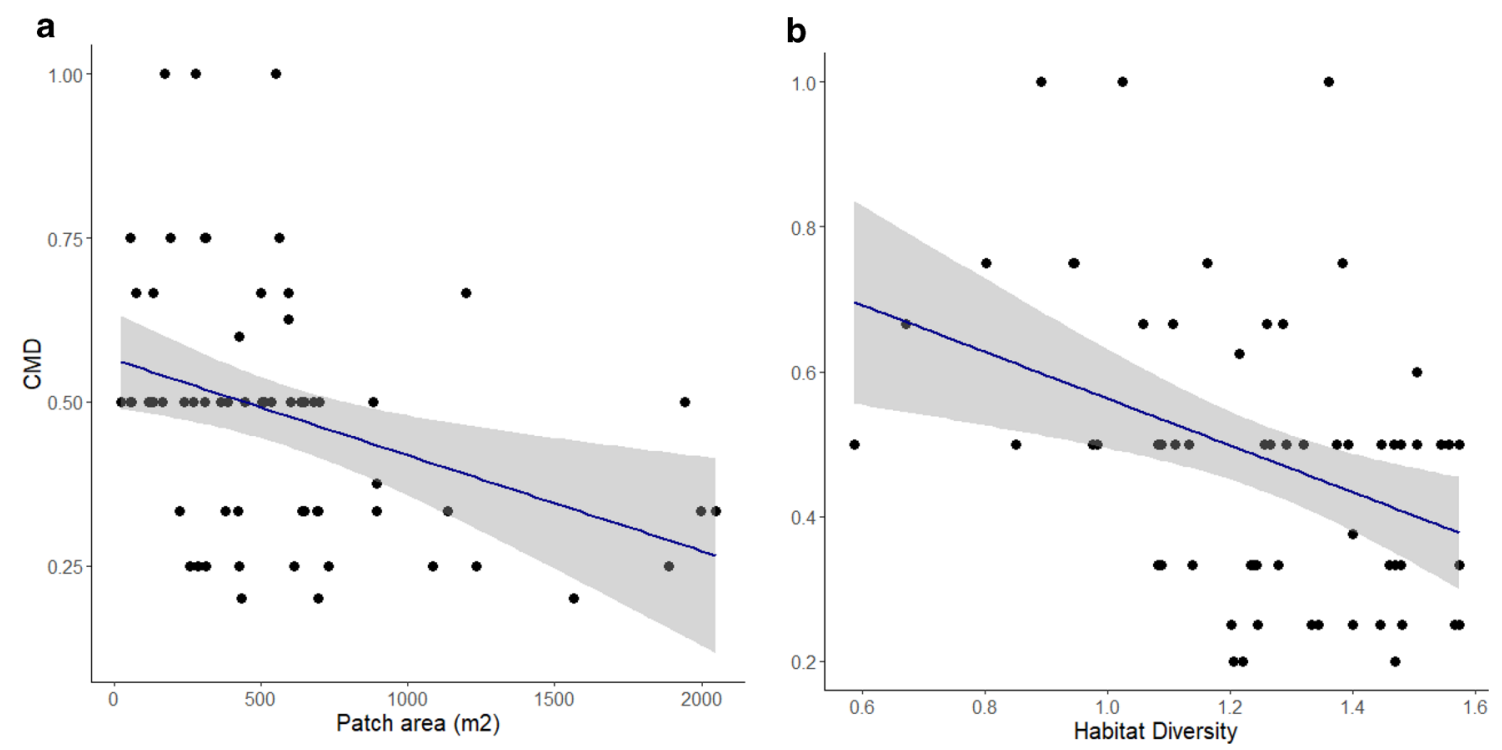

Fig. 3 Relationship between orthopteran community mean dispersal (CMD) and a patch area $\left(\mathrm{m}^{2}\right)$ and $\mathbf{b}$ habitat diversity
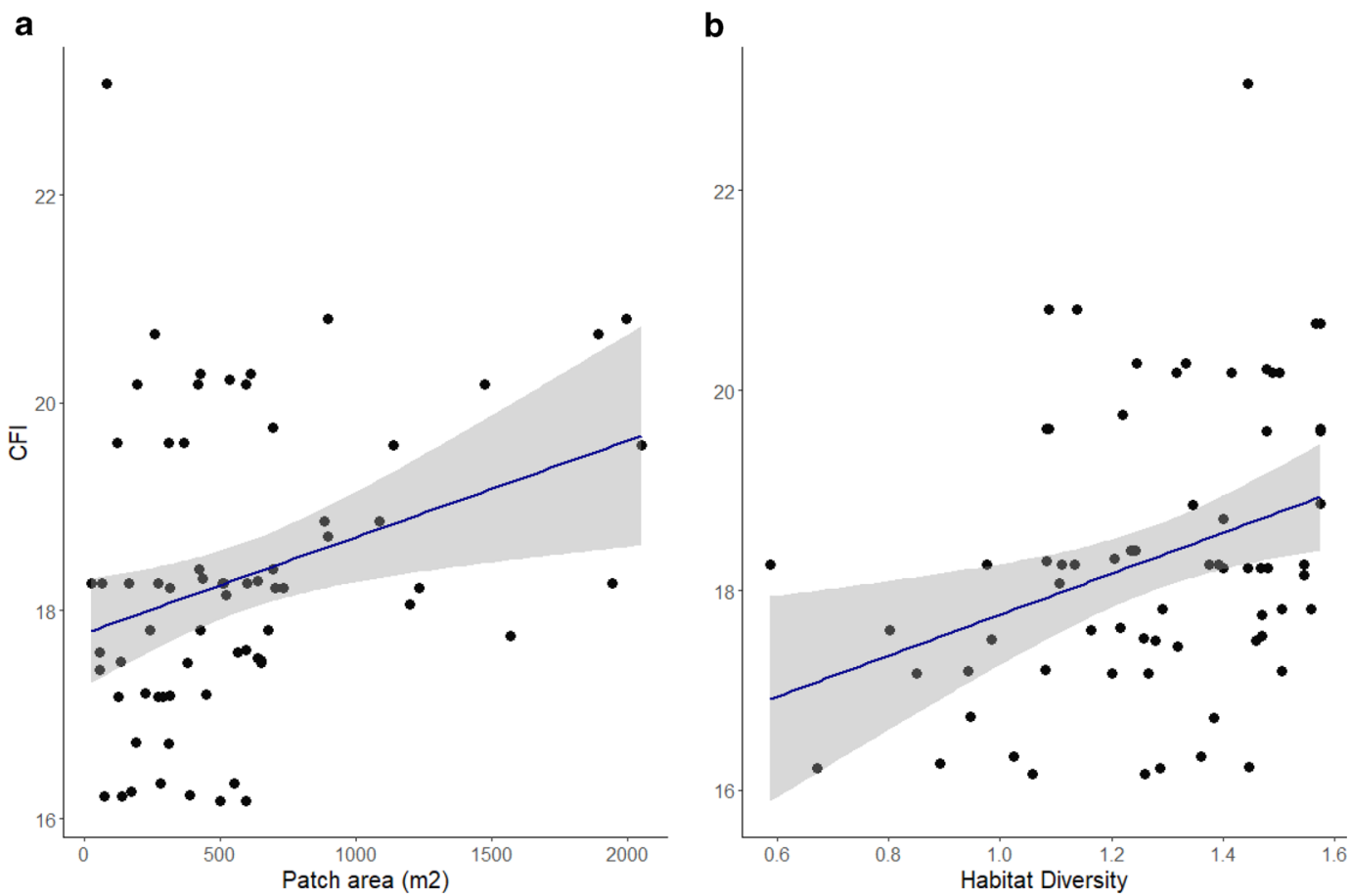

Fig. 4 Relationship between orthopteran community mean specialization—measured as the community mean farmland index (CFI)—and a patch area $\left(\mathrm{m}^{2}\right)$ and $\mathbf{b}$ habitat diversity

\section{Patch area not habitat diversity drives species richness}

We found no support for our initial hypothesis that habitat diversity and patch area are complementary mechanisms shaping species richness in field islands habitats (Triantis et al. 2005; Marini et al. 2010; Hortal et al. 2013). The overriding effect of patch habitat diversity found by Báldi (Báldi 2008) and Jonsson et al. (2009) was not found in our system. We found a marginal non-linear increase in species richness with patch area, with small but steeper and significant increases in smaller patches $\left(<894 \mathrm{~m}^{2}\right)$. Species 
richness accumulation curves corroborate these results (Supplementary Material F2). However, the effect of patch area on species richness was small $\left(\mathrm{R}^{2}\right.$ was $3 \%$ across all field islands and $7 \%$ in field islands $<894 \mathrm{~m}^{2}$ ) compared to previous studies (Marini et al. 2010). Marini et al. (2010) found a positive linear relationship between species richness and patch area for all species combined in arable landscapes, with sedentary species more strongly related to patch area and mobile species more strongly related with habitat diversity $\left(\mathrm{R}^{2}=20-49 \%\right)$.

There could be several reasons why the field islands in our study did not exhibit the expected positive species-area and species-habitat diversity relationships. These are likely related to factors acting at the local scale (e.g. plant productivity and interspecies competition). Local availability of food resources, such as grasses, determine assemblages of coexisting grasshopper species via interspecific competition (Chase and Belovsky 1994; Chase 1996; Belovsky 1997). Resource competition for grasses was not detected in our dataset. Indeed, proportion of grasses in the island did not correlate with species richness measures ( $r h o=0.15$, $\mathrm{p}$-value $=0.08$ ), indicating that grass cover was not limiting species richness. However, data on actual food biomass (instead of cover) and plant species presence are necessary to test this hypothesis. Interspecific competition for habitat and resources may be particularly fierce in these small fragmented and less connected field island habitats, thus, specie richness rapidly saturates to an average of 4 species per island in the range of patch areas investigated. Habitat patches may require to be larger than $2000 \mathrm{~m}^{2}$ to harbor more species and show a positive species richness area relationship. Indeed, previous studies that found positive orthopteran species-area relationship investigated much larger patches ranging from 0.1 ha to over 10.000 ha (Báldi and Kisbenedek 1999; Báldi 2008, Marini et al. 2010). Interestingly, Báldi and Kisbenedek (1999) study on orthopteran richness in steppe patches, included 8 patches smaller than 0.2 ha. In these patches, they found on average 3.4 and 4.5 species per patch in 1993 and 1994, which correspond to the threshold and mean values found in this study.

Species richness negatively correlated with proportion of arable land in the landscape. Orthopterans have been shown to be negatively affected by both local and landscape scale management intensity (Marini et al. 2007, 2010). At the landscape scale, an enhanced mortality from the mowing and ploughing of large areas is suggested to be the main constraint to high diversity of Orthoptera communities (Gardiner and Hill 2006). Although the effect of landscape was significant, the effect size was smaller compared to previous studies of orthopterans in grasslands (i.e. Marini et al. 2007, 2009), suggesting that field islands could act as refuges in highly managed landscapes. Despite low numbers of species per field island due to their intrinsic small size, our results suggests that taken altogether, a system of small field island can increase species numbers and include a large proportion of the regional species pool in arable landscapes (Fig. 2b, Supplementary Material F2).

\section{Patch area and habitat diversity impact orthopteran community}

Contrary to our initial hypothesis, that in low quality landscape we would find more mobile species that are better able to disperse, we did not find any effect of landscape quality on dispersal ability. Most of the non-agricultural land was covered by forest, a very low-quality habitat for grassland specialists. Therefore, landscape matrix may have been overall unsuitable for orthopterans to move around in this study site, hence a lack of landscape effect on mobility. In landscapes with unsuitable matrix, mobile species can be lost to a high degree (from e.g. predation) during dispersal; have a lowered likelihood to reach and establish in new habitats (Heidinger et al. 2013). The lack of isolation effect was somewhat surprising, as this has been observed on small scales in Orthopterans (Berggren et al. 2002). It is possible that the relatively small isolation distances of the patches (Mean $\pm \mathrm{SE}=21.5 \pm 2.8$ ) in combination with the croprotation system that some years includes lay, increase the opportunities for individuals to move out to the field islands.

On the other hand, patch characteristics influenced orthopteran assemblages. Smaller and less habitat diverse field islands were dominated by mobile orthopteran species whereas larger and more diverse field island were dominated by sedentary species. In addition, CFI increased with field island habitat diversity and marginally with area. Hence, orthoptera communities were there composed of species more dependent on high nature value farmland, i.e. less habitat generalist or widespread species, than in smaller and more homogenous field islands. This indicates that despite larger islands harboring similar number of species as smaller island, community composition differ between small and larger field islands and that habitat diversity is an important factor affecting orthopteran assemblages in field islands. Overall, more diverse and, to a lesser extent, larger field island appear to benefit more sedentary and habitat specialist species. This is possibly because patches with low diversity and smaller area may not be able to sustain viable populations of these species, and may serve more as stepping-stones or transient habitats to more mobile, widespread generalist species. Habitat clearance is a major threat to sedentary and specialist species as they will not be able to readily disperse into remnant habitat patches in the landscape. In addition, clearing is especially problematic for small patches, such as field islands, being allocated less value despite being able to retain similar biodiversity as large patches (Wintle et al. 2019). Our results indicate that 
protection of field islands and a management for increased habitat diversity in these patches is likely to be important for the maintenance of sedentary grassland arthropods in managed landscapes.

\section{Conservation value of small field islands}

In line with recent studies advocating the value of small habitats (Fahrig 2019; Wintle et al. 2019), our results indicate that also field islands are important habitats for orthopteran species in managed landscapes. The number of orthopteran species found across field islands was representative of the regional species pool, indicating that these habitats are suitable for grassland species in this part of the country. Additionally, the field islands may have a previously unrecognized value as habitat for sedentary species in managed landscapes. While there is no doubt that large, well-connected patches are required for biodiversity conservation and ecological processes, our results show the high conservation value of field islands patches, particularly in managed landscapes. The present findings indicate that relatively unpretentious looking landscape elements that remain stable over long time periods provide an important role in conserving orthopterans, and likely also for other specialized grassland dwelling insects, in agricultural landscapes in Sweden.

Acknowledgements Open access funding provided by Swedish University of Agricultural Sciences. We are grateful to Lina Lönnberg who gathered and shared the data on field islands characteristics. We thank Matthew Low who provided useful criticism of the manuscript.

\section{Compliance with ethical standards}

Conflict of interest The authors declare that they have no conflict of interest and that the manuscript has not been submitted for publication nor has it been published before in whole or in part elsewhere. All authors agree to its submission in the present form.

Open Access This article is licensed under a Creative Commons Attribution 4.0 International License, which permits use, sharing, adaptation, distribution and reproduction in any medium or format, as long as you give appropriate credit to the original author(s) and the source, provide a link to the Creative Commons licence, and indicate if changes were made. The images or other third party material in this article are included in the article's Creative Commons licence, unless indicated otherwise in a credit line to the material. If material is not included in the article's Creative Commons licence and your intended use is not permitted by statutory regulation or exceeds the permitted use, you will need to obtain permission directly from the copyright holder. To view a copy of this licence, visit http://creativecommons.org/licenses/by/4.0/.

\section{References}

Aavik T, Augenstein I, Bailey D et al (2008) What is the role of local landscape structure in the vegetation composition of field boundaries? Appl Veg Sci 11:375-386. https://doi. org/10.3170/2008-7-18486

Báldi A (2008) Habitat heterogeneity overrides the species-area relationship. J Biogeogr 35:675-681. https://doi.org/10.111 $1 / \mathrm{j} .1365-2699.2007 .01825 . \mathrm{x}$

Báldi A, Kisbenedek T (1999) Orthopterans in small steppe patches: an investigation for the best-fit model of the species-area curve and evidences for their non-random distribution in the patches. Acta Oecologica 20:125-132. https://doi.org/10.1016/S1146 $-609 X(99) 80025-3$

Belovsky GE (1997) Optimal foraging and community structure: the allometry of herbivore food selection and competition. Evol Ecol 11:641-672. https://doi.org/10.1023/A:1018430201230

Berggren Å, Carlson A, Kindvall O (2001) The effect of landscape composition on colonization success, growth rate and dispersal in introduced bush-crickets Metrioptera roeseli. J Anim Ecol 70:663-670. https://doi.org/10.1046/j.1365-2656.2001.00525.x

Berggren A, Birath B, Kindvall O (2002) Effect of corridors and habitat edges on dispersal behavior, movement rates, and movement angles in Roesel's Bush-Cricket (Metrioptera roeseli). Conserv Biol 16:1562-1569. https://doi.org/10.104 6/j.1523-1739.2002.01203.x

Brotons L, Mönkkönen M, Martin JL (2003) Are fragments islands? Landscape context and density-area relationships in boreal forest birds. Am Nat 162:343-357. https://doi.org/10.1086/376887

Chase JM (1996) Differential competitive interactions and the included niche: an experimental analysis with grasshoppers. Oikos 76:103-112. https://doi.org/10.2307/3545752

Chase JM, Belovsky GE (1994) Experimental evidence for the included niche. Am Nat 143:514-527

Cousins SAO (2006) Plant species richness in midfield islets and road verges - the effect of landscape fragmentation. Biol Conserv 4:500-509. https://doi.org/10.1016/j.biocon.2005.09.009

Deák B, Valkó O, Török P et al (2018) Landscape and habitat filters jointly drive richness and abundance of specialist plants in terrestrial habitat islands. Landsc Ecol 33:1117-1132. https://doi. org/10.1007/s10980-018-0660-x

Estades CF (2001) The effect of breeding-habitat patch size on bird population density. Landsc Ecol 16:161-173. https://doi. org/10.1023/A:1011197432467

EU Environment Green Infrastructure - Environment - European Commission. https://ec.europa.eu/environment/nature/ecosy stems/index_en.htm. Accessed 18 Nov 2019

Ewers RM, Didham RK (2006) Confounding factors in the detection of species responses to habitat fragmentation. Biol Rev 81:117-142. https://doi.org/10.1017/S1464793105006949

Fahrig L (2001) How much habitat is enough? Biol Conserv 100:6574. https://doi.org/10.1016/S0006-3207(00)00208-1

Fahrig L (2019) Habitat fragmentation: a long and tangled tale. Glob Ecol Biogeogr 28:33-41. https://doi.org/10.1111/geb.12839

Fartmann T, Krämer B, Stelzner F, Poniatowski D (2012) Orthoptera as ecological indicators for succession in steppe grassland. Ecol Ind 20:337-344. https://doi.org/10.1016/j.ecolind.2012.03.002

Fumy F, Löffler F, Samways MJ, Fartmann T (2020) Response of orthoptera assemblages to environmental change in a low-mountain range differs among grassland types. J Environ Manage 256:109919. https://doi.org/10.1016/j.jenvman.2019.109919

Gardiner T, Hill J, Chesmore D (2005) Review of the methods frequently used to estimate the abundance of orthoptera in grassland ecosystems. J Insect Conserv 9:151-173. https://doi. org/10.1007/s10841-005-2854-1

Gardiner T, Hill J (2006) Mortality of Orthoptera caused by mechanised mowing of grassland. Br J Entomol Nat Hist 19:38-40

Gibbons P, Boak M (2002) The value of paddock trees for regional conservation in an agricultural landscape. Ecol Manage Restor 3:205-210. https://doi.org/10.1046/j.1442-8903.2002.00114.x 
Heidinger IMM, Hein S, Feldhaar H, Poethke H-J (2013) The genetic structure of populations of Metrioptera bicolor in a spatially structured landscape: effects of dispersal barriers and geographic distance. Conserv Genet 14:299-311. https://doi. org/10.1007/s10592-013-0449-z

Hortal J, Carrascal LM, Triantis KA et al (2013) Species richness can decrease with altitude but not with habitat diversity. PNAS 110:E2149-E2150. https://doi.org/10.1073/pnas.1301663110

Jakobsson S, Fukamachi K, Cousins SAO (2016) Connectivity and management enables fast recovery of plant diversity in new linear grassland elements. J Veg Sci 27:19-28. https://doi. org/10.1111/jvs. 12344

Jonsson M, Yeates GW, Wardle DA (2009) Patterns of invertebrate density and taxonomic richness across gradients of area, isolation, and vegetation diversity in a lake-island system. Ecography 32:963-972. https://doi.org/10.1111/j.1600-0587.2009.05784.x

Kindvall O (1999) Dispersal in a metapopulation of the bush cricket, Metrioptera bicolor (Orthoptera: Tettigoniidae). J Anim Ecol 68:172-185. https://doi.org/10.1046/j.1365-2656.1999.00273.x

Le Roux DS, Ikin K, Lindenmayer DB et al (2015) Single large or several small? Applying biogeographic principles to tree-level conservation and biodiversity offsets. Biol Conserv 191:558566. https://doi.org/10.1016/j.biocon.2015.08.011

Lindenmayer D (2019) Small patches make critical contributions to biodiversity conservation. PNAS 116:717-719. https://doi. org/10.1073/pnas.1820169116

Lindenmayer DB, Laurance WF (2017) The ecology, distribution, conservation and management of large old trees. Biol Rev Camb Philos Soc 92:1434-1458. https://doi.org/10.1111/brv.12290

Lindgren JP, Cousins SAO (2017) Island biogeography theory outweighs habitat amount hypothesis in predicting plant species richness in small grassland remnants. Landsc Ecol 32:1895-1906. https://doi.org/10.1007/s10980-017-0544-5

Lindgren J, Lindborg R, Cousins SAO (2018) Local conditions in small habitats and surrounding landscape are important for pollination services, biological pest control and seed predation. Agric Ecosyst Environ 251:107-113. https://doi.org/10.1016/j.agee.2017.09.025

MacArthur RH, Wilson EO (1967) The theory of island biogeography. Princeton University Press, Princeton

Manning AD, Fischer J, Lindenmayer DB (2006) Scattered trees are keystone structures-implications for conservation. Biol Conserv 132:311-321. https://doi.org/10.1016/j.biocon.2006.04.023

Marini L, Fontana P, Scotton M, Klimek S (2007) Vascular plant and orthoptera diversity in relation to grassland management and landscape composition in the European Alps. J Appl Ecol 45:361-370. https://doi.org/10.1111/j.1365-2664.2007.01402.x

Marini L, Fontana P, Battisti A, Gaston KJ (2009) Agricultural management, vegetation traits and landscape drive orthopteran and butterfly diversity in a grassland-forest mosaic: a multi-scale approach. Insect Conserv Divers 2:213-220. https://doi.org/10. 1111/j.1752-4598.2009.00053.x

Marini L, Bommarco R, Fontana P, Battisti A (2010) Disentangling effects of habitat diversity and area on orthopteran species with contrasting mobility. Biol Conserv 143:2164-2171. https://doi. org/10.1016/j.biocon.2010.05.029

Muggeo VMR (2003) Estimating regression models with unknown break-points. Stat Med 22:3055-3071. https://doi.org/10.1002/ sim. 1545

NCE (2016) The sustainable infrastructure imperative: financing for better growth and development. The 2016 new climate economy report - the global commission on the economy and climate
Öckinger E, Smith HG (2007) Semi-natural grasslands as population sources for pollinating insects in agricultural landscapes. J Appl Ecol 44:50-59. https://doi.org/10.1111/j.1365-2664.2006.01250.x

Plue J, Cousins SAO (2013) Temporal dispersal in fragmented landscapes. Biol Conserv 160:250-262. https://doi.org/10.1016/j. biocon.2013.02.010

Poschlod P, Braun-Reichert R (2017) Small natural features with large ecological roles in ancient agricultural landscapes of Central Europe-history, value, status, and conservation. Biol Conserv 211:60-68. https://doi.org/10.1016/j.biocon.2016.12.016

Pulsford SA, Driscoll DA, Barton PS, Lindenmayer DB (2017) Remnant vegetation, plantings and fences are beneficial for reptiles in agricultural landscapes. J Appl Ecol 54:1710-1719. https://doi. org/10.1111/1365-2664.12923

Reinhardt K, Köhler G, Maas S et al (2005) Low dispersal ability and habitat specificity promote extinctions in rare but not in widespread species: the orthoptera of Germany. Ecography 28:593-602

Riede K (1998) Acoustic monitoring of Orthoptera and its potential for conservation. J Insect Conserv 2:217-223. https://doi. org/10.1023/A:1009695813606

Rosenzweig ML (1995) Species diversity in space and time. Cambridge University Press, Cambridge

Sánchez-Bayo F, Wyckhuys KAG (2019) Worldwide decline of the entomofauna: a review of its drivers. Biol Conserv 232:8-27. https ://doi.org/10.1016/j.biocon.2019.01.020

Stoate C, Báldi A, Beja P et al (2009) Ecological impacts of early 21 st century agricultural change in Europe-a review. J Environ Manage 91:22-46. https://doi.org/10.1016/j.jenvman.2009.07.005

Strid T (2010) Gräshoppor i Sverige - en fälthandbok

Sverige N (2016) Sweden's environmental objectives: an introduction. Swedish Environmental Protection Agency, Stockholm

The Nature Conservancy Building a Case for Green Infrastructure. https://www.nature.org/en-us/about-us/who-we-are/how-we-work/ working-with-companies/transforming-business-practices/build ing-a-case-for-green-infrastructure/. Accessed 18 Nov 2019

Triantis KA, Mylonas M, Weiser MD et al (2005) Species richness, environmental heterogeneity and area: a case study based on land snails in Skyros Archipelago (Aegean Sea, Greece). J Biogeogr 32:1727-1735

Tulloch AIT, Barnes MD, Ringma J et al (2016) Understanding the importance of small patches of habitat for conservation. J Appl Ecol 53:418-429. https://doi.org/10.1111/1365-2664.12547

Watson JEM, Whittaker RJ, Freudenberger D (2005) Bird community responses to habitat fragmentation: how consistent are they across landscapes? J Biogeogr 32:1353-1370

Weiss N, Zucchi H, Hochkirch A (2013) The effects of grassland management and aspect on Orthoptera diversity and abundance: site conditions are as important as management. Biodivers Conserv 22:2167-2178. https://doi.org/10.1007/s10531-012-0398-8

Wintle BA, Kujala H, Whitehead A et al (2019) Global synthesis of conservation studies reveals the importance of small habitat patches for biodiversity. PNAS 116:909-914. https://doi. org/10.1073/pnas.1813051115

Zuur A, Ieno EN, Walker N et al (2009) Mixed effects models and extensions in ecology with R. Springer, New York

Publisher's Note Springer Nature remains neutral with regard to jurisdictional claims in published maps and institutional affiliations. 